\title{
A. Tourovets. L'existence d'un culte royal zoroastrien en Perse achéménide : quelques réflexions sur un problème récurrent
}

\section{Rika Gyselen}

\section{(2) OpenEdition}

1 Journals

\section{Édition électronique}

URL : http://journals.openedition.org/abstractairanica/40806

DOI : $10.4000 /$ abstractairanica.40806

ISSN : 1961-960X

Éditeur :

CNRS (UMR 7528 Mondes iraniens et indiens), Éditions de l'IFRI

\section{Édition imprimée}

Date de publication : 1 décembre 2013

ISSN : 0240-8910

Référence électronique

Rika Gyselen, «A. Tourovets. L'existence d'un culte royal zoroastrien en Perse achéménide : quelques réflexions sur un problème récurrent », Abstracta Iranica [En ligne], Volume 32-33 | 2013, document 311, mis en ligne le 01 juillet 2016, consulté le 26 septembre 2020. URL : http:// journals.openedition.org/abstractairanica/40806; DOI : https://doi.org/10.4000/abstractairanica. 40806

Ce document a été généré automatiquement le 26 septembre 2020.

Tous droits réservés 


\title{
A. Tourovets. L'existence d'un culte royal zoroastrien en Perse achéménide : quelques réflexions sur un problème récurrent
}

\author{
Rika Gyselen
}

\section{RÉFÉRENCE}

A. Tourovets. «L'existence d'un culte royal zoroastrien en Perse achéménide : quelques réflexions sur un problème récurrent ». Varia Aegyptiaca et Orientalia Luc Limme in Honorem, Bruxelles, 2010, p. 197-214. [Acta Orientalia Belgica XXIII]

Survol des diverses hypothèses concernant les formes de religion qui ont cours à l'époque achéménide (ca. 558-330 av. n. è.), et en particulier du rapport de la dynastie achéménide avec le zoroastrisme (à distinguer du mazdéisme). En l'absence de nouvelles données à ces propos, on ne peut espérer voir présenter l'A. de nouvelles perspectives. On peut aussi regretter les nombreuses incohérences typographiques dans les notes et quelques coquilles.

\section{AUTEURS}

RIKA GYSELEN

CNRS, Mondes iranien et indien, Paris 